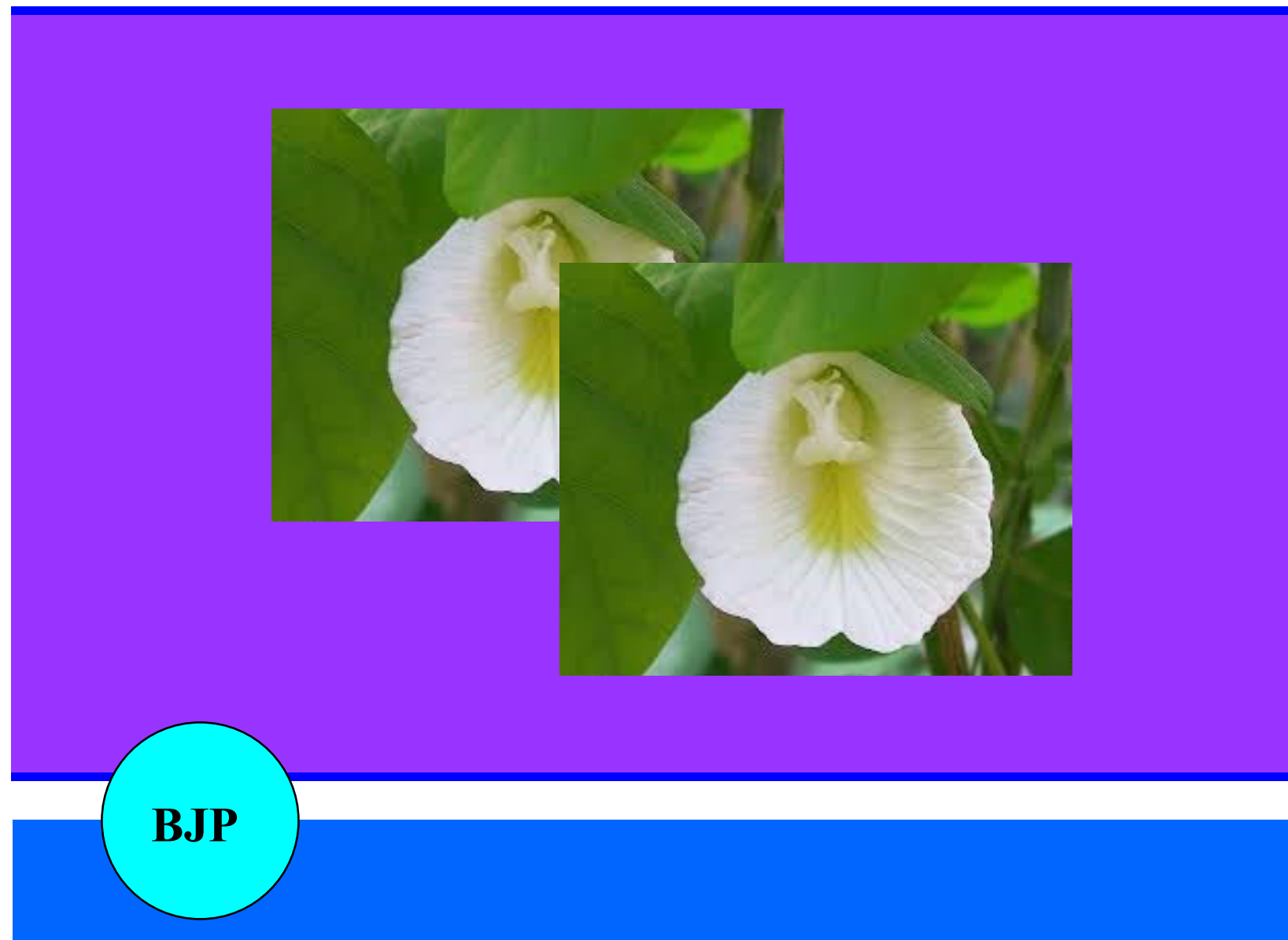

Bangladesh Journal of Pharmacology

Research Article

Antihyperlipidemic and renoprotective activities of methanolic extract of Canscora decussata extract in alloxan-induced diabetic rabbits 


\title{
Antihyperlipidemic and renoprotective activities of methanolic extract of Canscora decussata extract in alloxan-induced diabetic rabbits
}

\author{
Nadeem Irshad ${ }^{1,2}$, Muhammad Shoaib Akhtar², Yousaf Kamal', M. Imran Qayyum², \\ Abdul Malik ${ }^{2}$ and Hafiz Rashid Hussain² \\ ${ }^{1}$ Hamdard Institute of Pharmaceutical Sciences, Islamabad Campus, Islamabad 44000, Pakistan; ${ }^{2}$ Department of \\ Pharmacology, Faculty of Pharmacy, University of Sargodha, Sargodha 40100, Pakistan.
}

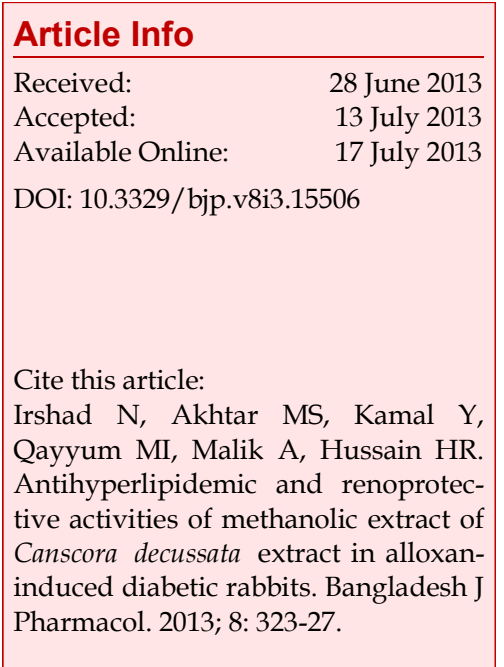

\begin{abstract}
The current study was designed to evaluate the hypolipidemic and renoprotective effects of methanolic extract of powdered Canscora decussata whole plant in the diabetic rabbits. Thirty rabbits were divided into five groups having 6 animals each including normal and diabetic controls groups, the remaining groups received methanolic extract in 400 and $600 \mathrm{mg} / \mathrm{kg}$ doses and another group got pioglitazone $(3 \mathrm{mg} / \mathrm{kg}$ ) for 30 days. Serum levels of triglycerides, total cholesterol, LDL-cholesterol, HDL-cholesterol, albumin, globulin and total proteins were estimated by using commercially available kits. The results showed that extract significantly $(p<0.01)$ decreased the raised parameters including triglyceride, total cholesterol and LDLcholesterol, atherogenic index, Coronary risk index up to normal values compared to diabetic rabbits. However, it significantly increased HDLcholesterol, albumin, globulin and total protein levels. Therefore, it is suggested that methanolic extract of $C$. decussata exerts hypolipidemic and renoprotective effects in the alloxan-induced diabetic rabbits.
\end{abstract}

\section{Introduction}

Hypercholesterolemia and hypertriglyceridemia have been reported to occur in the diabetic rabbits (Maciejewski et al., 2001; Wojtowiczet et al., 2004). High density lipoproteins also decrease in type 2 diabetic patients which ultimately lead to atheromatous disease (Rang et al., 2003). The development of diabetic nephropathy has been characterized by progressive increase in the excretion of protein, particularly albumin leading to end stage renal failure (Alberti et al., 1997). Diabetic nephropathy has been considered a major cause of endstage renal disease in many developed countries (CDC, 2005).

In developing countries like Pakistan, $80 \%$ of population depending on traditional medicine in primary health care (Grover and Yadav, 2004) because these drugs are of low cost and free from adverse effects (Akhtar et al., 2011). Ethnopharmacological and ethno botanical surveys indicate that more than 1200 plants are used worldwide in herbal medicine to treat diabetes (Ziyyat et al., 1997; El-Hilaly et al., 2003; Tahraoui et al., 2007). Among them Actinodaphne hookeri, Aegle marmelos, Bombax ceiba, Cajanus scarabaeoides, Eulophia herbacea, Gymnema lactiferum, Lagerstroemia speciosa, Mangifera indica, Meyna spinosa, Nigella sativa, Teucrium stocksianum Trichosanthes tricuspidata have shown antidiabetic effect in their scientifically designed studies (Prajapati et al., 2008; Ravi et al., 2009; Pattanayak et al., 2009; Tatiya et al., 2013; Bandara et al., 2009; Saha et al., 2009; Bhowmik et al., 2009; Sen et al., 2013; Khanam et al., 2009; Alamgeer et al., 2013; Bhavsar and Talele, 2013; Kulandaivel et al., 2013). 
The Canscora decussata plant (Family: Gentianaceae), locally known as Sankhahulee, has been used in the traditional medicine for the treatment of insanity, epilepsy and nervous debility. It has been found to contain triterpines, alkaloids, and xanthones (Kokate et al., 2002). Recently, Akhtar et al., 2012 have reported its hypoglycemic effects in normal as well as in diabetic rabbits. In folklore, it is reputed as a nervine tonic, alternative, and laxative (Shah et al., 2000). Diabetes affects both glucose and lipid metabolism (Sperling et al., 2000) while renal damage is its serious complication (Alberti, 1993).

Ipomoea staphylina leaves (Bag and Mumtaz, 2013), Sechium eduleon (Mumtaz et al., 2013), Nigella sativaon (Begum et al., 2006), Cinnamomum zeylanicum (Ullah et al., 2013), and grape seed and skin (Hamlaoui et al., 2012) extract shows renoprotective effect.

However, as far as ascertained, no scientific study was reported to assess the antihyperlipidemic and renoprotective activities of C. decussata in diabetes. Therefore, the current study was conducted to determine the antihyperlipidemic and renoprotective effects of methanolic extract of $C$. decussata in the diabetic rabbits.

\section{Material and Methods \\ Chemicals and plant material}

The plant C. decussata was collected from a village of Lahore, Pakistan in the month of August 2010 and got identified by the taxonomist of University of Sargodha, Sargodha. A voucher specimen (No. UOS/CD/333) was deposited in Department of Pharmacy, University of Sargodha. The plant was completely shade dried and powdered with herbal grinder. The powdered material was stored in well closed cellophane bags at $4^{\circ} \mathrm{C}$ in the refrigerator till further use. Chemicals used in the study include triglyceride, total cholesterol, LDL-cholesterol and HDL-cholesterol kits by Fluitest, Germany; alloxan monohydrate by Research Organics, USA; Methanol by Merck Chemical Co., Germany; and Gum acacia by Uni -Chem, Germany, pioglitazone was a generous gift from Maan Gee distributors, Sargodha.

\section{Experimental animals}

Healthy adult rabbits weighing 1,000-1,500 g were kept at animal house of the Department of Pharmay, Hamdard University Islamabad Campus, Islamabad. The animals were housed in stainless cages under standard laboratory condition (light period: 8:00 am to $8: 00 \mathrm{pm}, 21 \pm 2^{\circ} \mathrm{C}$, relative humidity $55 \%$, green fodder and water were available ad libitum).

\section{Preparation of $C$. decussata extract}

Methanolic extract of $C$. decussata whole plant was prepared by cold maceration. Then extract was dried with rotary evaporator.

\section{Induction of diabetes}

After overnight fasting, rabbits were made diabetic by intravenous injection of fresh solution of $150 \mathrm{mg}$ per $\mathrm{kg}$ of alloxan monohydrate in jugular vein. Rabbits received alloxan monohydrate was provided with a free access to water with $5 \%$ dextrose solution in order to protect them from hypoglycaemic shock (Akhtar et al, 2002). Three days (72 hours) after injecting the alloxan blood glucose level of surviving rabbits were measured with glucometer and rabbits having blood glucose level between 250-300 mg/dL were considered diabetic and used for further study (Olajide et al., 1999; Shani et al., 1974).

\section{Administration of drug suspensions}

The quantity of extract was calculated on body weight and triturated with about $10 \mathrm{~mL}$ of $2 \%$ aqueous gum solution and the final volume was always made up to $20 \mathrm{~mL}$. Then suspension was administered (p.o) to each animal by using a stomach tube and disposable syringe (Akhtar and Iqbal, 1991; Sivajothi et al., 2008).

\section{Experimental design}

The rabbits were divided into five groups of six animals each. Group 1 and 2 considered as normal and diabetic control and were administered orally $20 \mathrm{~mL}$ of $2 \%$ aqueous gum acacia solution daily for 30 days. The groups 3 and 4 were administered extract (400 and 600 $\mathrm{mg} / \mathrm{kg}$ OD), while group 5 received pioglitazone continuously for 30 days respectively. After 30 days blood samples were collected for the study.

\section{Biochemical analysis}

The total serum cholesterol, triglyceride and HDLs were estimated by enzymatic test kits using chemistry analyzer biolyser 100 (Merck Chemical Co., Germany). VLDL cholesterol and LDL-cholesterol were calculated using the Friedewald's et al., 1972 formula. Atherogenic index and coronary risk index was calculated by using Devaki et al., 2011 formula. Serum total protein and albumin content was deter-mined by standard procedures in an auto analyzer using standard kits.

\section{Statistical analysis}

The results are expressed as mean \pm SEM. The statistical analysis was carried out using paired t-test and oneway analysis (ANOVA). Statistical p value $<0.05$ was considered to be significant.

\section{Results and Discussion}

Effects of methanolic extract of $C$. decussata whole plant on serum triglyceride, cholesterol, LDL cholesterol, VLDL cholesterol, HDL-cholesterol, AI and CRI (mg/ $\mathrm{dL}$; mean \pm SEM) levels in alloxan-induced diabetic rabbits after 30 days of extract administration are given in Table I. The serum levels of triglyceride $(99.8 \pm 0.31$ $\mathrm{mg} / \mathrm{dL})$ and total cholesterol (129.9 $\pm 0.98 \mathrm{mg} / \mathrm{dL})$ of group treated with $400 \mathrm{mg} / \mathrm{kg}$ extract were found to be significantly $(\mathrm{p}<0.001)$ lowered as compared to untreated alloxan-induced diabetic. Whereas, the serum level of HDL-cholesterol $(34.6 \pm 0.6 \mathrm{mg} / \mathrm{dL})$ of group treated with $400 \mathrm{mg} / \mathrm{kg}$ extract was found to be 
significantly $(\mathrm{p}<0.001)$ increased as compared to untreated alloxan-induced diabetic. The AI and CRI also decreased significantly $(\mathrm{p}<0.001)$ as compared to diabetic group. The serum levels of triglyceride $(83.6 \pm$ $0.7 \mathrm{mg} / \mathrm{dL})$, total cholesterol (123.7 $\pm 0.78 \mathrm{mg} / \mathrm{dL}), \mathrm{LDL}$ -cholesterol $(67.3 \pm 1.4 \mathrm{mg} / \mathrm{dL})$ and VLDL-cholesterol $(16.7 \pm 0.4 \mathrm{mg} / \mathrm{dL})$ of group treated with $600 \mathrm{mg} / \mathrm{kg}$ extract were found to be significantly $(p<0.001)$ lowered as compared to untreated alloxan-induced diabetic group. Whereas, the serum level of HDLcholesterol $(39.7 \pm 1.1 \mathrm{mg} / \mathrm{dL})$ of group treated with $600 \mathrm{mg} / \mathrm{kg}$ of methanolic extract were found to be significantly $(\mathrm{p}<0.001)$ increased as compared to untreated alloxan-induced diabetic group. AI and CRI also significantly lowered as compared to diabetic control group. The serum level of HDL-cholesterol $(37.4 \pm 0.2 \mathrm{mg} / \mathrm{dL})$ of group treated with pioglitazone were found to be significantly $(p<0.001)$ increased as compared to untreated alloxan-induced diabetic group (Table I).

Effects of methanolic extract of $C$. decussata whole plant on serum total protein, albumin, and globulin and A/G ratio in alloxan induced diabetic rabbits after 30 days of extract administration are given in Table II. The serum levels of total protein $(7.5 \pm 0.02 \mathrm{~g} / \mathrm{dL})$, albumin $(4.5 \pm$ $0.03 \mathrm{~g} / \mathrm{dL}$ ) of group treated with methanolic extract in dosing $400 \mathrm{mg} / \mathrm{kg}$ were found to be significantly $(\mathrm{p}<0.05)$ increased as compared to untreated alloxaninduced diabetic group. The serum levels of total protein $(7.6 \pm 0.02 \mathrm{~g} / \mathrm{dL})$, albumin $(4.8 \pm 0.03 \mathrm{~g} / \mathrm{dL})$, globulin $(3.1 \pm 0.3 \mathrm{~g} / \mathrm{dL})$ and $\mathrm{A} / \mathrm{G}$ ratio $(1.5 \pm 0.1 \mathrm{~g} / \mathrm{dL})$ of group treated with extract in dosing $600 \mathrm{mg} / \mathrm{kg}$ were found to be significantly $(p<0.05)$ increased as compared to untreated alloxan-induced diabetic group. Similarly, the serum levels of total protein $(6.5 \pm 0.2 \mathrm{~g} /$ $\mathrm{dL})$, albumin $(4.2 \pm 0.1 \mathrm{~g} / \mathrm{dL})$, globulin $(2.3 \pm 0.1 \mathrm{~g} / \mathrm{dL})$ and $\mathrm{A} / \mathrm{G}$ ratio $(1.8 \pm 0.01 \mathrm{~g} / \mathrm{dL})$ of group treated with pioglitazone in dosing $3 \mathrm{mg} / \mathrm{kg}$ were found to be significantly $(\mathrm{p}<0.05)$ increased as compared to untreated alloxan-induced diabetic group.

\section{Discussion}

Diabetic patients have more chances to develop atheromatous complications such as ischemic heart diseases (Way et al., 2001). The decrease level of high density lipoprotein in diabetic patient is also the leading cause of atheromatous diseases (Rang et al., 2003). Oral administration of methanolic extract of $C$. decussata cause an increase in HDL and reduction in total cholesterol, triglycerides, LDL and VLDL which protect diabetic patients from atheromatous disease. The continuous administration of extract produced beneficial effect against hyperlipidemia associated with hyperglycemia in a dose dependent manner. Standard drug pioglitazone also increased serum HDL while reduces the total cholesterol, triglycerides, LDL and VLDL in dose dependent manner as reported by

Table I

\begin{tabular}{|c|c|c|c|c|c|c|c|}
\hline \multicolumn{8}{|c|}{$\begin{array}{l}\text { Effects of methanolic extract of } C \text {. decussata on serum cholesterol, triglyceride, LDL, VLDL, HDL, } \\
\text { atherogenic index and coronary risk index (mg/dL) levels in alloxan-induced diabetic rabbits after } 30 \text { days of } \\
\text { administra-tion }\end{array}$} \\
\hline Groups & $\begin{array}{c}\text { Cholesterol } \\
\mathrm{mg} / \mathrm{dL}\end{array}$ & $\begin{array}{c}\text { Triglyceride } \\
\text { mg/dL }\end{array}$ & $\begin{array}{l}\mathrm{HDL} \\
\mathrm{mg} / \mathrm{dL}\end{array}$ & $\begin{array}{c}\mathrm{LDL} \\
\mathrm{mg} / \mathrm{dL}\end{array}$ & $\begin{array}{l}\text { VLDL } \\
\mathrm{mg} / \mathrm{dL}\end{array}$ & $\begin{array}{l}\text { Atherogenic } \\
\text { indexmg/dL }\end{array}$ & $\begin{array}{l}\text { Coronary } \\
\text { risk index } \\
\mathrm{mg} / \mathrm{dL}\end{array}$ \\
\hline Normal control & $121.0 \pm 0.9$ & $80.6 \pm 0.7$ & $42.0 \pm 1.2$ & $58.7 \pm 0.6$ & $20.5 \pm 0.7$ & $1.3 \pm 0.01$ & $2.8 \pm 0.02$ \\
\hline Diabetic control & $266.3 \pm 1.5$ & $218.8 \pm 1.4$ & $29.7 \pm 0.7$ & $191.3 \pm 0.7$ & $45.5 \pm 1.0$ & $6.4 \pm 0.4$ & $8.9 \pm 0.3$ \\
\hline $\begin{array}{l}\text { Methanolic } \\
\text { extract } 400 \mathrm{mg}\end{array}$ & $129.9 \pm 1.0^{\mathrm{b}}$ & $99.8 \pm 0.3^{b}$ & $34.6 \pm 0.6^{b}$ & $75.3 \pm 1.3^{b}$ & $19.9 \pm 0.6^{b}$ & $2.1 \pm 0.1^{b}$ & $3.7 \pm 0.2^{b}$ \\
\hline $\begin{array}{l}\text { Methanolic } \\
\text { extract } 600 \mathrm{mg}\end{array}$ & $123.7 \pm 0.8^{b}$ & $83.6 \pm 0.7^{b}$ & $39.7 \pm 1.1^{b}$ & $67.3 \pm 1.4^{b}$ & $16.7 \pm 0.4^{b}$ & $1.6 \pm 0.02^{b}$ & $3.1 \pm 0.3^{b}$ \\
\hline $\begin{array}{l}\text { Pioglitazone } \\
\text { treated }\end{array}$ & $147.5 \pm 1.0^{b}$ & $87.0 \pm 0.03 b$ & $37.4 \pm 0.2 \mathrm{~b}$ & $92.6 \pm 1.2 \mathrm{~b}$ & $17.4 \pm 0.4^{b}$ & $2.4 \pm 0.01^{b}$ & $3.9 \pm 0.1^{b}$ \\
\hline
\end{tabular}

Table II

Effect of methanolic extract of C. decussata on the concentration of total protein, albumin, globulin and Ay $\mathrm{G}$ ratio $(\mathrm{g} / \mathrm{dL})$ in serum of control and experimental groups after 30 days

\begin{tabular}{|lcrrr|}
\hline Groups & Total protein & Albumin & Globulin & A/G Ratio \\
\hline Normal control & $8.0 \pm 0.1$ & $5.0 \pm 0.02$ & $3.1 \pm 0.1$ & $1.5 \pm 0.03$ \\
Diabetic control & $4.4 \pm 0.03$ & $2.3 \pm 0.1$ & $2.1 \pm 0.1$ & $1.0 \pm 0.1$ \\
Methanolic extract $400 \mathrm{mg}$ & $7.5 \pm 0.02^{\mathrm{b}}$ & $4.5 \pm 0.03^{\mathrm{a}}$ & $2.7 \pm 0.01^{\mathrm{c}}$ & $1.6 \pm 0.04^{\mathrm{a}}$ \\
Methanolic extract $600 \mathrm{mg}$ & $7.6 \pm 0.02^{\mathrm{b}}$ & $4.8 \pm 0.03^{\mathrm{b}}$ & $3.1 \pm 0.3^{\mathrm{a}}$ & $1.5 \pm 0.1^{\mathrm{a}}$ \\
Pioglitazone treated & $6.5 \pm 0.2^{\mathrm{a}}$ & $4.2 \pm 0.1^{\mathrm{a}}$ & $2.3 \pm 0.1^{\mathrm{a}}$ & $1.8 \pm 0.01^{\mathrm{a}}$ \\
Values are expressed as mean $\pm \mathrm{SEM} ; \mathrm{n}=6$; ${ }^{\mathrm{a}} \mathrm{p}<0.05{ }^{\mathrm{b}} \mathrm{p}<0.001, \mathrm{c} \mathrm{p}>0.05$ considered statistically significant as compared to diabetic control group \\
\hline
\end{tabular}


Kakadiya and Shah (2010). The antihyperlipidemic activity of the test extract would be due to its control of hyperglycemia which elevates the triglyceride, total cholesterol and LDL levels (Maciejewski et al., 2001). Several studies have reported that atherogenic index is an excellent predictor of HD risk and monitor for the effectiveness of lipid-lowering therapies. But, the LDL$\mathrm{C} / \mathrm{HDL}-\mathrm{C}$ ratio has been considered more prognostic than LDL-C or HDL-C alone (Natarajan et al., 2003). In the present study the test extract significantly reduced the AI as well as TC/HDL-cholesterol ratio which show its protective effect against cardiovascular dis-eases. Similar results have reported for $B$. tomentosa which significantly reduced the atherogenic and cardiac risk index in diabetic rats (Devaki et al., 2011). The protein profile parameters are also disturbed during diabetes mellitus as reported by Sumana and Suryawanshi (2001) in rats. The extract of C. decussata has also shown improvement in the insulin secretion and reverses the altered protein profile in a dose dependent manner by exerting the protein sparing effect. Generally, significant increase in urinary excretion of protein, albumin and glucose levels indicates the impaired renal function in diabetes. However, the treatments with herbal remedies have been found to prevent such changes (Tedong et al., 2006). Peroxisome proliferatoractivated receptor-gamma agonists have been reported to have direct beneficial effects on the diabetic renal diseases. They have shown to reduce proteinuria and improve glomerulosclerosis, both in animal and human diabetic nephropathic studies (Baylis et al., 2003), which is also shown in this study. In addition, Ohga et al., (2007) reported that pioglitazone ameliorates renal injury may be by the inhibition of NF-kB activation, ICAM-1 expression and macrophage infiltration in streptozotocin-induced diabetic rats. The present study has thus duly supported the alleged medicinal use of the plant in the traditional medicine.

It conclusion methanolic extract of $C$. decussata has been observed to exert significant and consistent hypolipidemic and renoprotective effects in the diabetic rabbits which also confirm the presence of such active principle (s) which have the maximum solubility in methanol solvent.

\section{References}

Akhtar MS, Iqbal J. Evaluation of hypoglycemic effect of Achyranthes aspera, Linn. In normal and diabetic rabbits. J Ethnopharmacol. 1991; 31: 49-57.

Akhtar MS, Khan MA, Malik MT. Hypoglycemic activity of Alpinia galangal rhizome and its extracts in rabbits. Fitoterapia 2002; 73: 623-28.

Akhtar MS, Nadeem M, Rashid, Bashir S. Hypoglycaemic activity of different fractions of Berberis aristata root-bark in normal and alloxan diabetic rabbits. Can J App Sci. 2011; 2: 16-28.

Alamgeer, Rashid M, Bashir S, Mushtaq MN, Khan HU, Malik MNH, Qayyum A, Shafeeq ur Rahaman M. Comparative hypoglycemic activity of different extracts of Teucrium stocksianum in diabetic rabbits. Bangladesh J Pharmacol. 2013; 8: 186-93.

Alberti KGMM, Zimmet P, Defronzo RA, Keen H. International textbook of diabetes mellitus. $2^{\text {nd }}$ ed. Chichester, John Wiley and Sons, 1997, p 1379.

Alberti KGMM, Problems related to definitions and epidemiology of type 2 diabetes mellitus: Studies throughout the world. Diabetologia, 1993; 36; 978-84.

Bag AK, Mumtaz SMF. Hepatoprotective and nephroprotective activity of hydroalcoholic extract of Ipomoea staphylina leaves. Bangladesh J Pharmacol. 2013; 8: 263-68.

Bandara T, Rokeya B, Khan S, Ali L, Ekanayake S, Jansz ER, Balasubramanium K. Effects of Gymnema lactiferum leaves on glycemic and lipidemic status in type 2 diabetes subjects. Bangladesh J Pharmacol. 2009; 4: 92-95.

Batteridge J. Lipid disorders in diabetes mellitus. In: Textbook of diabetes. William G (eds). 2nd ed. London, Blackwell Science, 1997, pp 1-31.

Bayle C, Atzpodien EA, Freshour G. Peroxisome proliferators activated receptor- $\gamma$ agonist provides superior renal protection versus angiotensin-converting enzyme inhibition in a rat model of type 2 diabetes with obesity. J Pharmacol Exp Ther. 2003; 307: 854-60.

Begum NA, Dewan ZF, Nahar N, Mamun MIR. Effect of nhexane extract of Nigella sativaon gentamicin-induced nephrotoxicity in rats. Bangladesh J Pharmacol. 2006; 1: 1620.

Bhavsar C, Talele GS. Potential anti-diabetic activity of Bombax ceiba. Bangladesh J Pharmacol. 2013; 8: 102-06.

Bhowmik A, Khan LA, Akhter M, Rokeya B. Studies on the antidiabetic effects of Mangifera indica stem-barks and leaves on non diabetic, type 1 and 2 diabetic model rats. Bangladesh J Pharmacol. 2009; 4: 110-14.

Bnouham M, Mekhfi H, Legssyer A, Ziyyat A. Medicinal plants used in the treatment of diabetes in Morocco. Int J Diabetes Metab. 2002; 10: 33-50.

Buckingham RE, Al-Barazanji KA, Toseland CN. Peroxisome proliferators-activated receptor- $\gamma$ agonist, rosiglitazone, protects against nephropathy and pancreatic islet abnormalities in Zucker fatty rats. Diabetes 1998; 47: 1326-34.

Centers for Disease Control and Prevention (CDC). Incidence of end-stage renal disease among persons with diabetesUnited States, 1990-2002. MMWR Morb Mortal Wkly Rep. 2005; 54: 1097-1100.

Devaki K, Beulah U, Akila G, Narmadha R, Gopalakrishnan VK. Glucose lowering effect of aqueous extract of Bauhinia tomentosa L. on alloxan induced type 2 diabetes mellitus in Wistar albino rats. JBCP. 2011; 2: 167-74.

El-Hilaly J, Hmamouchi M, Lyoussi B. Ethnobotanical studies and economic evaluation of medicinal plants in Taounate province (Northern Morocco). J Ethnopharmacol. 2003; 86: 149-58.

Friedewald WT, Levy RI, Fradrickson DS. Estimation of concentration of low density lipoprotein cholesterol in plasma without the use of preparative ultracentrifuge. Clin Chem. 1972; 18: 499-502.

Grover JK, Yadav SP. Pharmacological actions and potential uses of Momordica charantia: A review. J Ethnopharmacol, 2004; 93: 123-32.

Hamlaoui S, Samti O, Mokni M, Limam N, Carrier A, Limam 
F, Amri M, Aouani E, Marzouki L. Protective effect of grape seed and skin extract on high dosage garlic-induced renal oxidative stress. Bangladesh J Pharmacol. 2012; 7: 54-62.

Irshad N, Akhtar MS, Bashir S, Malik A, Kamal, Y. Hypoglycaemic effects of Canscora decussata (Schult) wholeplant in normal and alloxan-induced diabetic rabbits. J Ethnopharmacol. 2012; (under consideration)

Kakadiya J, Shah NJ. Hypoglycemic and hypolipidemic activity of pioglitazone in normal and streptozotocinnicotinamide induced diabetic rats. Pharmacologyonline 2010; 1: 1-7.

Khanam M, Dewan ZF. Effects of the crude and the n-hexane extract of Nigella sativa Linn. (kalajira) upon diabetic rats. Bangladesh J Pharmacol. 2009; 4: 17-20.

Kokate CK, Purohit AP, Gokhale SB. Pharmacognosy 19th ed. Pune, Nirali Prakashan, 2002; pp 524-25.

Kulandaivel S, Bajpai P, Sivakumar T. Anti-hyperglycemic activity of Trichosanthes tricuspidata root extract. Bangladesh J Pharmacol. 2013; 8: 305-10.

Laakso M. Epidemiology of diabetic dyslipidemia. Diabetic Rev; 1995; 3; 408-22.

Maciejewski R, Rucinski P, Burski K, Figura T. Changes in glucose, cholesterol and serum lipid fraction levels in experimental diabetes. Ann Univ Mariae Curie Sklodowska. 2001; 56: 363-68.

McCarthy KJ, Routh RE, Shaw W. Troglitazone halts diabetic glomerulosclerosis by blockade of mesangial expansion. Kidney Int. 2000; 58: 2341-50.

Mumtaz SMF, Paul S, Bag AK. Effect of Sechium edule on chemical induced kidney damage in experimental animals. Bangladesh J Pharmacol. 2013; 8: 28-35.

Natarajan S, Glick H, Criqui M, Horowitz D, Lipsitz SR, Kinosian B. Cholesterol measures to identify and treat individuals at risk for coronary heart disease. Am J Prev Med. 2003; 25: 50-57.

Ohga S, Shikata K, Yozai K. Thiazolidinedione ameliorates renal injury in experimental diabetic rats through antiinflammatory effects mediated by inhibition of NF-kB activation. Am J Physiol Renal Physiol. 2007; 292: 1141-50.

Olajide OA, Awe S, Makinde JM. Purgative effect of the methanol extract of Morinda, Lucida. Fitoterapia 1999; 70: 199 -204 .

Pattanayak S, Nayak SS, Panda D, Shende V. Hypoglycemic of Cajanus scarabaeoides in glucose overloaded and streptozotocin-induced diabetic rats. Bangladesh J Pharmacol. 2009; 4: 131-35.

Prajapati DD, Patel NM, Savadi RV, Akki KS, Mruthunjaya K. Alleviation of alloxan-induced diabetes and its complications in rats by Actinodaphne hookeri leaf extract. Bangladesh J Pharmacol. 2008; 3: 102-06.

Ravi S, Sadashiva CT, Tamizmani T, Balasubramanian T, Rupeshkumar M, Balachandran I. In vitro glucose uptake by isolated rat hemi-diaphragm study of Aegle marmelos Correa root. Bangladesh J Pharmacol. 2009; 4: 65-68.

Rahman AU, Zaman K. Medicinal plants with hypoglycemic activity. J Ethnopharmacol. 1989; 26: 1-55.

Rang HP, Dale MM, Ritter JM, Moore PK (eds). Atherosclerosis and lipoprotein metabolism. In: The text-book of pharmacology. London, Churchill Livingstone/Elsevier, 2003, p 311.
Roman-Ramos R, Florez-Saenz JL, Alarcon-Aguilar FJ. Antihyperglycemic effect of some edible plants. J Ethnopharmacol. 1995; 48: 25-32.

Saha BK, Bhuiyan MNH, Mazumder Haque KKMF. Hypoglycemic activity of Lagerstroemia speciosa L. extract on streptozotocin-induced diabetic rat: Underlying mechanism of action. Bangladesh J Pharmacol. 2009; 4: 79-83.

Sen S, De B, Devanna N, Chakraborty R. Hypoglycaemic and hypolipidemic effect of Meyna spinosa leaves in high fat dietalloxan induced type 2 diabetic rats. Bangladesh J Pharmacol. 2013; 8: 181-85.

Shah Y, Tangalos EG, Petersen RC. Mild cognitive impairment. When is it a precursor to Alzheimer's disease. Geriatrics 2000; 55: 65-68.

Shani J, Gold Schmied A, Joseph B, Abronson Z, Sneman FG. Hypoglycemic effects of Trigonella faenum graecum and Lupinus termis (Leguminosae) seed and their major alkaloids in alloxan-diabetic and normal rats. Arch Int Pharmacodyn Ther. 1974; 210: 27-37.

Sivajothi V, Dey A, Jayakar B, Rajkapoor B. Antihyperglycemic and anti-oxidant effect of Phyllanthus rheedii on streptozotocin-induced diabetic rats. Iranian J Pharma Res. 2008; 7: 53-59.

Sperling MA, Saunders PA. Diabetes mellitus. In: Nelson textbook of pediatrics. Behrman RE, Kliegman RM, Jenson HB (eds). 2000, pp 1767-91.

Sumana G, Suryawanshi SA. Effect of Vinca rossa extracts in treatment of alloxan diabetes in male albino rats. Ind J Exp Bio. 2001; 39: 748-59.

Tahraoui A, El-Hilaly J, Israili ZH, Lyoussi B. Ethnopharmacological survey of plants used in the traditional treatment of hypertension and diabetes in South-Eastern Morocco (Errachidia province). J Ethnopharmacol. 2007; 110: 105-17.

Tatiya AU, Puranik PM, Surana SJ, Patil YS, Mutha RE. Evaluation of hypolipidemic, antidiabetic and anti-oxidant activity of Eulophia herbacea tubers. Bangladesh J Pharmacol. 2013; 8: 269-75.

Tedong L, Dimo T, Dzeufi PD, Asongalem E, Sokeng DS, Callard P, Flejou F, Kamtchouing P, .Antihyperglycemic and renal protective activities of Anacardium occidentale leaves in streptozotocin induced diabetic rats. Afr J Trad CAM. 2006; 3: 23-35.

Ullah N, Khan MA, Khan T, Ahmad W. Bioactive traditional plant Cinnamomum zeylanicum successfully combat against nephrotoxic effects of aminoglycosides. Bangladesh J Pharmacol. 2013; 8: 15-21.

Way KJ, Kata IN, King GL. Protein kinase C and the development of diabetic vascular complication. Diabet Med. 2001; 18: 945.

Wojtowicz Z, Wrona W, Kis G, Blaszczak M, Solecka A. Serum total cholesterol, triglyceride and high density lipoprotein levels in rabbits during the course of experimental diabetes. Ann Univ Mariae Curie Sklodowska, 2004; 59; 258-60.

Ziyat A, Legssyer A, Mekhfi H, Dassouli A, Serhrouchni M, Benjelloun W. Phytotherapy of hypertension and diabetes in oriental Morocco. J Ethnopharmacol. 1997; 58: 45-54.

Author Info
Nadeem Irshad (Principal contact)
e-mail: ndmirshad@gmail.com

